\title{
Extensive Reading: Resources and Strategies for Intermediate and Advanced Learners of Norwegian
}

Jennifer Duggan

NTNU

Anna Maria Krulatz

NTNU

\begin{abstract}
Research has demonstrated the value of extensive reading to second language acquisition. However, reading in a second language classroom, in particular when access to reading materials is limited, is often restricted to passages available in the textbook. Therefore, teachers play an important role in promoting reading through creating classroom libraries, providing suggestions, including in-class reading activities, and talking to students about the role of reading in language development. Aiming to empower teachers of Norwegian to stock their libraries with varied reading materials and use those materials in their classrooms, this paper gives an overview of some available sources that can be used with intermediate (B1B2) and advanced (C1-C2) learners as well as methods for including extensive reading in the classroom. Following a brief overview of the theoretical background on extensive reading, the paper explains how the discussed materials can be used to promote extensive reading in a second language both in the classroom and at home, including the use of specific strategies and activities such as free voluntary reading, sustained silent reading, book flood, literature circles, and book battles.
\end{abstract}

\section{Introduction}

Research suggests that extensive reading of compelling material can have a positive impact on the acquisition of a second language (Krashen, Power of Reading). Extensive reading can consolidate previously learned vocabulary and grammar, foster acquisition of language, and increase intrinsic motivation for language study (Nation, "Teaching"). Various approaches to promoting extensive reading in- and outside of the classroom include free voluntary reading (FVR) and book flood. FVR is an instructional practice that fosters literacy by encouraging students to read for pleasure and allows them to engage with reading materials of their choice without requiring them to write book reports or answer comprehension question (Krashen, Power of Reading). A similar approach, Warwick B. Elley and Francis Mangubhai's book flood (Elley and Mangubhai; Elley, "Potential"; Elley, "Conclusion"; Mangubhai) is defined as "a flood of high-interest, readily accessible books in the classroom" and has been shown, through various studies, to "accelerate acquisition" (Elley, "Conclusion" 238).

In order to foster motivation to read, it is crucial that texts are compelling (Krashen, "Compelling"). Sheltered popular literature, a construct proposed by Stephen Krashen ("Free Voluntary Reading"), refers to the use of interesting, comprehensible, popular literature in a second language classroom. Popular literature can include graphic novels, mysteries, magazines, and newspapers. Such materials should be available through the classroom library, and the main role of the teacher is to encourage students to read extensively, both in- and outside of the classroom (Kim and Krashen). 
Nevertheless, finding compelling texts that are also at the right level of difficulty can be challenging, and the textbook materials typically used in second language classes are often uninteresting (Graves, 2000; Howard \& Major, 2009). Identifying compelling reading materials at the right proficiency level in Norwegian is a major challenge for teachers who want to promote language acquisition through extensive reading.

Heyoung Kim and Krashen recommend that in order to encourage second language learners to read, teachers should (a) provide access to a wider variety of books, (b) provide easier access to books, (c) provide guidance, and (d) tell the learners about the benefits of reading (28). The present paper specifically addresses points (a) and (c), as it examines various reading materials teachers of Norwegian can select for their classroom libraries, discusses the advantages of using resources such as young adult literature, graphic novels, literature in translation, and online resources in developing Norwegian language competence, and presents sample activities and techniques that promote extensive reading.

Because we are not aware of any literature that specifically discusses the benefits of extensive reading in the acquisition of Norwegian as a second language, we base our discussion in findings and recommendations from research undertaken in other language learning contexts.

\section{Compelling Input and the Power of Reading}

Applied linguists and language teachers alike agree that language acquisition cannot happen without comprehensible input. Stephen Krashen postulates that in addition to being comprehensible, linguistic input should also be compelling, i.e., so interesting that the acquirer does not even notice that the input is in a second language and acquires language without a conscious intention to do so ("Compelling"). Compelling texts are texts that readers cannot put down, texts that they want to keep reading, even if the language is a bit challenging. Research on content-based instruction, an approach to language teaching that uses interesting, cognitively demanding non-linguistic content to teach language, suggests that student motivation increases when the focus of instruction is on content related to students' interests (see, e.g., Grabe and Stoller). On the contrary, as Richard Day and Julian Bamford point out, "in the absence of interesting texts, very little is possible" (29).

Empirical studies have demonstrated many benefits of extensive reading in a second language, including vocabulary acquisition (Pigada and Schmitt), motivation to read (Judge), reading fluency (Belgar and Hunt), and literacy development (Krashen). While purposes of reading vary, ranging from reading for general or specific information to reading to learn or reading to write, it has been suggested that reading for pleasure plays a crucial role in second language acquisition, as it exposes language learners to large quantities of compelling input at the level of their linguistic competence (Grabe and Stoller; Krashen, "Compelling").

It is crucial that reading materials be carefully selected so that they match learners' proficiency levels. Reading difficult texts that are beyond learners' level of competence can lead to major problems with comprehension (Nation, "Teaching") and thus decrease motivation to read (Kim and Krashen). Findings from research suggest that only about 2-5\% of words in a text can be unknown to language learners if they are to be able to guess the words' meanings from context (Nation, "Teaching"; Schmitt et al.). Extensive reading of materials that contain some new words and grammatical structures provides readers with meaning-focused input, while materials that are very easy to read foster fluency development (Nation, "Teaching"). 
However, simply selecting proficiency-level appropriate materials does not guarantee that language learners will be inclined to engage in reading as a means of improving their language skills (Kim and Krashen). Paul Nation points out that language learners should read books that are not only at the right level for them but are also interesting and thus enjoyable ("Principles"). In the same vein, Fredricka L. Stoller stresses the importance of allowing students to choose what they read, arguing that such practices "can empower students and lead to more student engagement in reading" (152). Where learners' reading preferences vary from those of the teacher, learners' choices should be prioritized (Nation, "Teaching").

\section{Reading and Vocabulary Acquisition}

Among its other benefits, extensive reading in a second language is positively associated with gains in vocabulary, mainly due to exposure to words that are frequently repeated in varied contexts (Nation, "Principles"). Incidental learning of vocabulary through extensive reading can be advantageous in comparison to direct vocabulary instruction as it is meaning-focused, contextualized, learner-based, and thus individualized and pedagogically efficient (Huckin and Coady; Nation, "Principles").

How much vocabulary can be acquired through incidental reading can be limited by various factors, such as learners' previous vocabulary knowledge, number of exposures to a new word, and access to word strategies (Huckin and Coady). Nevertheless, research suggests that reading for pleasure can improve knowledge of the spelling, meaning, and grammatical characteristics of words (Pigada and Schmitt). Studies that examine incidental learning (e.g., Horst et al.; Horst and Meara) confirm that reading results in meaningful amounts of vocabulary learning. Similarly, studies on extensive reading (e.g., Nation and Wang Mingtzu) suggest that appropriately used graded readers can lead to substantial gains in vocabulary.

\section{Literature in a Second Language Classroom}

Literature provides useful, authentic, and culturally situated input for language learners. Further, trends in language education are pushing educators to move beyond the textbook to find diverse input for learners. As Janice Bland and Christiane Lütge suggest, "language as the object and sole focus of study is gradually diminishing, and content-based ... classrooms are becoming the norm in many types of school [, while] ... Intercultural Communicative Competence ... is likely to gain further ... importance" (1). Bland and Lütge also emphasize that the goal of reading literature in a second language is no longer simply to develop literacy in a traditional sense but to foster multimodal literacies, critical abilities, and intercultural competence, as well as to empower the learner.

Furthermore, literature can be used to engage learners in a variety of ways. Approaches such as FVR and book flood can be used both in- and outside of the classroom to bolster students' learning, and such approaches encourage students to read books on topics of interest at a level learners themselves deem appropriate and accessible.

Moreover, literature allows for a wide-range of interactive classroom activities, from acting out scenes from books to debates, discussions, or students' creating book-inspired written output. More generally, extensive reading allows students to gain knowledge and vocabulary related to a variety of topics, while intensive reading, such as guided close readings of shorter texts, can help students to gain the skills necessary to get the most from the texts they read (Nation, "Teaching"). In what follows, we present a discussion of the benefits of various types of texts in the second language classroom. 


\section{Graphic Novels}

Graphic novels and comics more generally, both in- and outside the classroom, have received attention in recent years. This began with comic artists Will Eisner's and, later, Scott McCloud's foundational explorations of comics' semantics and semiotics. More recently, the discussion of comics has expanded to include linguists (see, e.g., Bramlett; Varnum and Gibbons) and scholars in second language education (see, e.g., Bland, "Fairy Tales"; Bland, Children's Literature; Syma and Weiner). What follows is a brief overview of research on the usefulness of the graphic novel in the second language classroom.

Much of the research on the use of comics and graphic novels in the classroom discusses their use at primary and secondary school, or in entry-level second language courses. As Christina L. Blanch and Thalia M. Mulvihill argue, however, "this form of learning is beneficial to students of all ages.... [Comics and graphic novels] are legitimate forms of literature and can be used as teaching tools in higher education" (35). However, several researchers (see, e.g., Blanch and Mulvihill; Bucky Carter; Whitt) have argued that in order to gain the most from comics, teachers first need to overcome the stigma that comics are the realm of geeky boys (Blanch and Mulvihill 41). As the next step, they need to help their students to develop the tools they require to interpret comics and actively use them in their language learning.

Several critics have focused on the "tremendous potential [of graphic novels] for crossing the curricular gap between the study of language and the abrupt start to literary studies employing adult literature" (Bland, Children's Literature 75; see also BurwitzMelzer), while others have focused on the entertainment value and accessibility of the comic form as opposed to a textbook (see, e.g., Blanch and Mulvihill). Yet others have commented on the value of the visual, particularly in the language classroom (see, e.g., Bland, "Fairy Tales"; Bland, Children's Literature; Burwitz-Melzer).

Eisner and McCloud were some of the first to discuss the art of graphic novels as a sign system similar to a language. McCloud pointed out, in particular, that both written and sign languages and comic art were "juxtaposed ... images in deliberate sequence" (8). More recently, linguists have discussed how comics use image schemas and conceptual metaphors to communicate (see, e.g., Cohn; Potsch and Williams). This can be useful in the language classroom, as students are increasingly visually literate. However, many students have not received training in interpreting visual stimuli. It is important to keep in mind, too, as several critics have stressed, that the sign systems used in comics from different cultures are subtly but noticeably different (see, e.g., Leber-Cook \& Cook; McCloud). It is therefore important for educators to remember that students from diverse backgrounds may not be familiar with the sign system of Western comics. For this reason, Bland (Children's Literature) and Eva Burwitz-Melzer both underscore the importance of training students so that they are better able to interpret pictures. They argue that educators using comics in the language classroom must discuss the art of comics with their students. This allows the students to make better use of symbols and elements such as color, distance, and perspective to interpret pictures and gain a better context for new vocabulary, better enabling them to interpret new vocabulary in the target language. It may be worthwhile to include a class on common graphic novel symbols as well as on elements of design, such as colors and their cultural and emotional associations. Both McCloud and Frank Serafini provide good direction regarding how to access meaning from multimodal texts.

Alice Leber-Cook and Roy T. Cook underscore that "when teaching adult learners ..., comics turn out to be an immensely promising ... ingredient of literacy instruction" in the 
second language classroom, because they neither belittle the learner by providing linguistically appropriate material with content intended for younger learners nor overly challenge the learner (28). They point out that while adult language learners "at the very basic level ... typically do not have the critical mass of basic vocabulary necessary to decipher meanings [through words alone,] ... they do have ... the ability to understand pictures" (29), and this can aid them to infer the meaning of new vocabulary without needing a dictionary. In particular, Leber-Cook and Cook emphasize the usefulness of graphic novels in classrooms in which students are not literate in their mother tongue (30), but their arguments are salient even for advanced language learners.

Perhaps the most important aspect of comics to language learning is their emphasis on conversational, communicative language. Because much of the text is dialogue, presented in speech balloons, it is often informal, colloquial, or written in dialect. This is why it is particularly useful to introduce comics and graphic novels in second language classes, as students may not be able to practice conversing frequently outside of the classroom. This is especially important to students learning less commonly taught — and less commonly spoken-languages, because it is difficult to find situations in which one can converse outside of the classroom, and it is therefore difficult for learners to gain communicative proficiency. Linda Smetana et al., who recommend the use of graphic novels with deaf leaners of English, suggest that graphic novels allow learners who have limited or no access to conversation to acquire conversational, informal language, and thereby to increase their success in acquiring more complex language (230). Smetana et al. further suggest that "the average comic book introduces [language learners to] ... five times as many words as they were likely to be exposed to in the average child-adult conversation.... This genre provides a scaffolded resource for vocabulary and syntax" (231).

The Norwegian graphic novel industry has been gaining critical acclaim in Europe over the past decade, especially following the publication of Munch and Herr Merz, discussed below. Teachers looking for comics in Norwegian have many sources available to them. The Oslo Comics Expo (OCX) takes place every year at Serieteket, a special section of the Oslo Library dedicated to Norwegian and international comics, in Grünerløkka in Oslo. ${ }^{i}$ The Norwegian Comics Forum (NTF) runs Norway's Comics Museum ${ }^{\mathrm{ii}}$ and the National Comics

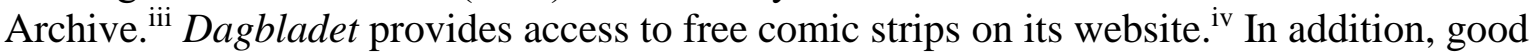
translations of many comic series and graphic novels are available in Norwegian; for example, Marjane Satrapi's Persepolis (No Comprendo, 2005) is available in Norwegian, the original French, and a number of other languages, as is David B.'s Epilepsy (No Comprendo, 2007). Tove Jansson's Mummi comics (Cappelen Damm, 2008-2012), which were originally published in Swedish, are considered classics throughout Scandinavia. They are discussed in detail below.

We encourage those wishing to recommend materials originally published in Norwegian to consider Lise Myhre's comic Nemi, published serially since 1997. We also recommend graphic novels, such as Steffan Kverneland's Munch (No Comprendo, 2013), reviewed in detail below, and Lars Fiske's Herr Merz (No Comprendo, 2012).

Recommended graphic novel: Munch by Steffan Kverneland. This award-winning graphic novel depicts Edvard Munch's life and artistic processes as well as a postmodern, autobiographic narrative of Kverneland's inspiration for and making of Munch. Kverneland used original materials such as Munch's diaries, paintings, sketches, and letters to, from, and about the artist to create the graphic novel. This pastiche of original and historical material 
means that the language level is relatively high $(\mathrm{C} 1-\mathrm{C} 2)$ - there is some use of specialized vocabulary and of nineteenth-century language, as well as dialects and some Danish and Swedish. Nevertheless, the visual support should to some degree compensate for these linguistic hurdles, and the images can aid second-language readers to comprehend the text. This graphic novel can also help students to gain communicative competence by exposing them to Norwegian dialects.

Because Munch is about an artist and focuses on the artistic process, elements of artistic design are pronounced and exaggerated throughout the book. It is therefore a useful graphic novel to use when introducing students to the concept that artistic elements of graphic novels are contextual clues that can be mined for meaning. Information regarding mood or symbolization gleaned from the images in Munch can guide students to interpret new words more precisely and aid them in understanding the content of a panel or series of panels.

Munch is available in Danish, Dutch, French, German, Polish, and Swedish. Online rumors also swirl about a forthcoming English edition. This means that additional scaffolding can be provided to struggling learners in the form of mother-tongue versions of the book, which may be a more enjoyable way to access unknown word meanings than looking up words in a dictionary. It may also help the learners to notice structural, lexical, and semantic similarities and differences between their mother tongue and Norwegian while presenting them with contextualized uses of the new word.

Because this is a graphic novel intended for adults, it includes some themes and images to which some may object, including sex, nudity, alcohol and drug abuse, and violence. Teachers should therefore consider students' cultural background before recommending the text.

Recommended comic series: The collected Mummi comics by Tove Jansson. Tove Jansson's beloved Mummitroller children's books and comics are both accessible and enjoyable. More importantly, they are considered children's classics in Norway, so becoming familiar with them provides learners with a useful conversational topic as well as cultural knowledge.

The black-and-white comics to which we will limit our analysis were originally written in Swedish in the mid-twentieth century. Anders Heger's Norwegian translations have been collected in a series of five books by Cappelen Damm (2008-2012). These delightful comics - featuring the anthropomorphized, fantasy Mummitroller as protagonists - cover everyday topics, such as the change of the seasons, winter sports, party preparations, falling in (or out) of love, and cooking. As is discussed at length above, comics are extremely useful tools for acquiring communicative language. That the Mummi comics cover such everyday topics makes them particularly useful for lower intermediate (A2-B1) and intermediate (B1B2) students of Norwegian who are aiming to augment their lexicon and develop conversational fluency.

Usefully, each book of collected comics in the series comprises several short stories in comic form. The second book, on which we have chosen to focus, comprises four such stories of approximately twenty pages each. The benefits of this are twofold: firstly, their length makes the comics easy to use in class or to set as required readings. Secondly, and much more importantly, the manageable length of the stories and their comic form allow language learners to feel as though they are making more and swifter progress than they would reading a traditional text, which bolsters their confidence as readers of the Norwegian language. They are therefore also appropriate to recommend as independent reading. 
Because we have already discussed the benefits of visual scaffolding above, we will not repeat ourselves here. It is worth mentioning, however, that these comics are in black-andwhite, so students can focus more on elements such as distance, form, and line. The visuals in these comics are less complex than the visuals in a graphic novel like Munch, so these comics may be more appropriate for learners with little experience interpreting images.

Some of the short story collections in the Mummi series, e.g., Det usynlige barn, are similarly accessible, but have few illustrations. Such collections are appropriate for intermediate (B1-B2) learners. Single stories can easily be read by an intermediate reader in one sitting. This increases confidence and fosters a feeling of progress.

\section{Literature in Translation}

Although we do not have space to discuss literature in translation at length in this article, very briefly, we wish to draw Norwegian teachers' attention to the great number of works translated from English, in particular, but also other languages-from French (see graphic novels, above) to Japanese (e.g., Haruki Murakami's novels) — into Norwegian.

Familiar books translated from languages in which learners are already fluent allow learners to access complex novels that might otherwise be too difficult for them. For example, learners who are already familiar with the Harry Potter series may find Torstein Bugge Høverstad's award-winning Norwegian translations of the novels more accessible than other works of similar complexity simply because they are already familiar with the context and content of the story, as well as the vocabulary used in the books.

Using works in translation can be problematic, however. Those who choose to work with literature in translation should screen the books before providing them to students. Some translations from English to Norwegian, for example, retain English syntax, directly translate idiomatic expressions, or use unnatural collocations.

\section{Newspapers and Magazines}

Other materials that can be used to teach Norwegian include newspapers and magazines. Specifically, Klar Tale $e^{v}$ is a weekly "easy to read" newspaper published both online and in print. Klar Tale's intended audience is Norwegian native speakers with reading impediments, but it is also a great resource for lower- to upper- intermediate (A2-B2) learners of Norwegian. The newspaper is divided into the following sections, which address a wide range of interesting topics: Norway, the world, culture, sports, and special topics. Access to the articles online is free, and the content of the printed materials is also available as a podcast. In addition, a weekly activity ("ukens oppgave"), which accompanies a selected article, is available for free in Microsoft Word format.

\section{Other Resources}

There are many other Norwegian compelling reading materials for learners of varied proficiency levels. The organization Leser sфker bok ("Readers looking for a book") has created a website ${ }^{\mathrm{vi}}$ providing a great overview of publications available in accessible language. The section "Litt å lese" ("A little to read") provides suggestions about easy texts, including fiction, non-fiction, and comics, that are recommended for struggling or beginning (A1) readers. The use of simple grammar and vocabulary, larger print, shorter sections, and compelling content make these books a great resource for Norwegian language learners.

Children's books, young adult literature, and adult literature are listed in separate sections. In addition, the website has a Top 100 list of books selected based on the texts' readability and 
literary merit, as well as a monthly theme section ("Månedens tema"). Each book is briefly summarized and accompanied by information about the target audience, the topic, the genre, and the number of pages. Brief excerpts from each book are also included, enabling readers to choose what most interests them.

\section{Integrating FVR in the Classroom}

Although FVR has been emphasized in first-language classrooms for decades and in second language classrooms more recently, it has usually been discussed as an appropriate component of language instruction for children rather than adults. Although adult language courses still very often require rote memorization and grammar drills, there is growing interest in integrating reading as part of language learning in adult classrooms (see, e.g., Paran), and "research indicates that learners who ... are given the opportunity to read literature and respond to it ... benefit linguistically and enjoy the experience" (Paran 480). However, integrating reading programs can occasionally be difficult because "language teachers normally receive no training in using literary texts in the classroom" (Paran 480). In addition to encouraging teachers to suggest that their students read outside of the classroom, this paper will therefore give some ideas of appropriate methods of including FVR in classrooms.

\section{Sustained Silent Reading (SSR)}

A form of FVR, sustained silent reading (SSR), or independent reading, an idea introduced over fifty years ago by Lyman C. Hunt, gained particular ground in schools in the 1980s and 1990s with the sudden popularity of Drop Everything and Read (DEAR) programs, made famous through Beverly Cleary's Ramona series. ${ }^{\text {vii }}$ To integrate in-class SSR time, teachers can simply aside 10-30 minutes at the beginning or end of class for students to read texts of their choice. Silence should be maintained throughout reading time. Writing or speaking can also be integrated through follow-up activities such as discussion circles, reflection logs or journals, review writing, or giving presentations.

\section{Literary Circles}

Literature circles in classrooms are similar to book clubs outside of classrooms: students are placed in or self-select small groups, and each group picks one text to read and discuss. Alternatively, the students' choice of text, if a limited number of texts is made available by the teacher, can determine the students' groups. This activity allows the students autonomy while allowing the teacher to choose texts that reflect the course curriculum.

\section{Battle of the Books}

Over the last several years, the Battle of the Books has gained popularity in American libraries, but it has also successfully been integrated into the classroom, ${ }^{\text {viii }}$ and the activity can be used with other types of texts, such as poems or magazine articles. These battles mimic the style of a sports tournament: two texts are paired off against one another, and the winning text advances to the next round. To integrate a battle, the teacher chooses a minimum of four texts. Students read the texts in groups, in brackets of two. Each group then has to decide which of the two texts advances to the next bracket. At the end, the entire class decides on a winning text.

\section{Conclusion}


This paper focused on the use of compelling reading materials to promote language acquisition for intermediate and advanced learners of Norwegian, and it aimed to help teachers of Norwegian to identify varied reading materials for their classroom libraries. We have provided an overview of up-to-date research on the use of extensive reading in the foreign language teaching, focusing on how it enables vocabulary acquisition and increases learners' motivation to learn. We also discussed how Norwegian language teachers can ensure access to a wider variety of books in their classrooms, provide guidance on material selection, include reading in the classroom, and aid the reading process itself.

For students to gain advanced skills in Norwegian, it is particularly important that teachers of Norwegian use authentic materials like books, newspapers, magazines, children's literature, and graphic novels. As the classics, such as the works of Henrik Ibsen or Bjørnstjerne Bjørnson, are often written in language beyond learners' proficiency levels, we focused on providing some alternative suggestions. Specifically, we discussed the benefits of using graphic novels and children's literature in teaching Norwegian and included a brief overview of other available sources, such as the newspaper Klar Tale, written in simplified language, and a website, ${ }^{\mathrm{ix}}$ which can provide Norwegian language teachers with further ideas.

We chose to focus in detail on the graphic novel Munch by Kverneland because of its cultural content and because of its emphasis on symbolic uses of artistic elements, such as color, which allow teachers to show students salient examples of the symbolic use of artistic elements in the graphic novel medium. This can help students to develop their ability to use graphic novels for language learning. Similarly, we discussed Tove Jansson's Mummi comics because of their accessibility and their popularity in Scandinavia, which makes them culturally important.

Extensive reading in- or outside the second language classroom is an invaluable resource learners should be encouraged to use, especially when access to comprehensible input is limited to weekly or bi-weekly sessions,. Extensive reading of compelling materials results in incidental vocabulary acquisition, including the acquisition of colloquial expressions, boosted motivation to learn the target language, and overall improved language proficiency. We therefore hope to see an increased use of authentic, compelling reading materials in all Norwegian language classrooms. 


\section{Works Cited}

Belgar, David, and Alan Hunt. "Pleasure Reading and Reading Rate Gains." Reading in a Foreign Language 26.1 (2014): 29-48.

Blanch, Christina L., and Thalia M. Mulvihill, "The Attitudes of Some Students on the Use of Comics in Higher Education." Graphic Novels and Comics in the Classroom: Essays on the Educational Power of Sequential Art. Ed. Karya K. Syma and Robert G. Weiner. Jefferson and London: McFarland and Company, 2013. 35-48. ProQuest. Web. 1 Oct. 2015.

Bland, Janice. Children's Literature and Learner Empowerment: Children and Teenagers in English Language Education. London: Bloomsbury, 2013. ProQuest. Web. 27 Aug. 2015.

---. "Fairy Tales with a Difference: Creating a continuum from Primary to Secondary ELT." Children's Literature in Second Language Education. Ed. Janice Bland and Christiane Lütge. London: Bloomsbury, 2012. 85-94. Ebrary. Web. 15 Sept. 2015.

Bland, Janice, and Christiane Lütge, eda. Children's Literature in Second Language Education. London: Bloomsbury, 2012. Ebrary. Web. 15 Sept. 2015.

Bramlett, Frank, ed. Linguistics and the Study of Comics. London: Palgrave, 2012. Palgrave Connect. Web. 14 Oct. 2015.

Bucky Carter, J. (2013). “'What the-?' Pre-Service Teachers Meet and Grapple over Graphic Novels in the Classroom." Graphic Novels and Comics in the Classroom: Essays on the Educational Power of Sequential Art. Ed. Karya K. Syma and Robert G. Weiner. Jefferson and London: McFarland and Company, 2013. 58-72. ProQuest. Web. 1 Oct. 2015.

Burwitz-Melzer, Eva. "Approaching Literary and Language Competence: Picturebooks and Graphic Novels in the EFL Classroom." Children's Literature in Second Language Education. Ed. Janice Bland and Christiane Lütge. London: Bloomsbury, 2012. 55-70. Ebrary. Web. 15 Sept. 2015.

Cohn, Neil. "Comics, Linguistics, and Visual Language: The Past and Future of a Field." Linguistics and the Study of Comics. Ed. Frank Bramlett. London: Palgrave, 2012. 92118. Palgrave Connect. Web. 14 Oct. 2015.

Day, Richard R., and Julian Bamford. Extensive Reading in the Second Language Classroom. Cambridge: Cambridge UP, 1998. Print.

Eisner, Will. Comics \& Sequential Art. Tamarac: Poorhouse, 1985. Print.

---. Graphic Storytelling and Visual Narrative. Tamarac: Poorhouse, 1996. Print.

Elley, Warwick B. "Conclusion: What Have We Learned?" International Journal of Educational Research 35.2 (2001): 237-46. ResearchGate. Web. 12 Oct. 2015.

---. "The Potential of Book Floods for Raising Literacy Levels." International Review of Education 46.3/4 (2000): 233-55. JStor. Web. 12 Oct. 2015.

Elley, Warwick B., and Francis Mangubhai. "The Impact of Reading on Second Language Learning." Reading Research Quarterly 19.1 (1983): 53-67. JStor. Web. 12 Oct. 2015.

Grabe, William, and Fredricka L. Stoller. "Content-Based Instruction: Research Foundations." The Content-Based Classroom: Perspectives on Integrating Language and Content. Eds. Marguerite Ann Snow and Donna M. Brinton. White Plains: Addison Wesley-Longman, 1997. 5-21. Print.

---. Teaching and Researching Reading. Harlow: Longman, 2002. Print. 
Graves, Kathleen. Designing Language Courses. Canada: Newbury House, 2000. Print.

Horst, Marlise, Tom Cobb, and Paul Meara. "Beyond A Clockwork Orange: Acquiring Second Language Vocabulary through Reading." Reading in a Foreign Language 11.2 (1998): 207-23. Web. 17 Oct. 2015.

Horst, Marlise, and Paul Meara. "Test of a Model for Predicting Second Language Lexical Growth through Reading." The Canadian Modern Language Review 56 (1999): 30828. Web. 17 Oct. 2015.

Howard, Jocelyn and Major, Jae. "Guidelines for designing effective English language teaching materials." The TESOLANZ Journal 12 (2004): 50-58. Web. 10 Nov. 2016.

Huckin, Thomas, and James Coady. "Incidental Vocabulary Acquisition in a Foreign Language: A Review.” Studies in Second Language Acquisition 21 (1999): 181-93. Cambridge Journals. Web. 18 Oct. 2015.

Jansson, Tove. Mummi: Tone Janssons samlede tegneserier, Bind 2. Trans. (Anders Heger. Oslo: Cappelen Damm, 2009. Print.

Judge, Patrick B. "Driven to Read: Enthusiastic Readers in a Japanese High School's Extensive Reading Program. Reading in a Foreign Language 23.2 (2011): 161-86. Web. 15 Oct. 2015.

Kim, Heyoung, and Stephen Krashen. "Why Don't Language Acquirers Take Advantage of the Power of Reading? TESOL Journal (Spring 1997): 26-9. Print.

Krashen, Stephen. "The Compelling (Not Just Interesting) Input Hypothesis." The English Connection. A Publication of KOTESOL 15.3 (2011): n.p. PDF file.

---. "Do We Learn to Read by Reading? The Relationship between Free Voluntary Reading and Reading Ability. Linguistics in Context: Connecting Observation and Understanding. Ed. Deborah Tannen. Norwood: Ablex, 1988. 269-98. Print.

---. "Free Voluntary Reading: New Research, Applications, and Controversies." Singapore: RELC Conference, 2004. PDF file.

---. The Power of Reading: Insights from the Research. 2nd ed. Westport: Libraries Unlimited, 2004.

Kverneland, Steffan. Munch. Oslo: No Comprendo, 2013. Print.

Leber-Cook, Alice, and Roy T. Cook. "Stigmatization, Multimodality and Metaphor: Comics in the Adult English as a Second Language Classroom." Graphic Novels and Comics in the Classroom: Essays on the Educational Power of Sequential Art. Ed. Karya K. Syma and Robert G. Weiner. Jefferson and London: McFarland and Company, 2013. 23-34. ProQuest. Web. 1 Oct. 2015.

McCloud, Scott. Understanding Comics. New York: HarperPerennial, 1994. Print.

Mangubhai, Francis. "Book Floods and Comprehendible Input Floods: Providing Ideal Conditions for Second Language Acquisition." International Journal of Educational Research 35.2 (2001): 147-56. Science Direct. Web. 17 Oct. 2015.

Nation, Paul. "Principles Guiding Vocabulary Learning through Extensive Reading." Reading in a Foreign Language 27.1 (2015): 136-45. Print.

---. Teaching ESL/EFL Reading and Writing. London and New York: Routledge, 2009. Print.

Nation, Paul, and Karen Wang Ming-tzu. "Graded Readers and Vocabulary." Reading in a Foreign Language 12.2 (1999): 355-80. Web. Oct. 182015.

Paran, Amos. "The Role of Literature in Instructed Foreign Language Learning and Teaching: An Evidence-Based Survey." Language Teaching 41.4 (2008): 465-96. Cambridge Journals. Web. 30 Jun. 2015. 
Pigada, Maria, and Norbert Schmitt. "Vocabulary Acquisition from Extensive Reading: A Case Study.” Reading in a Foreign Language 18.1 (2006): 1-28. Web. 17 Oct. 2015.

Potsch, Elisabeth, and Robert F. Williams. Image schemas and conceptual metaphor in action comics. Linguistics and the Study of Comics. Ed. Frank Bramlett. London: Palgrave, 2012. 13-36. Palgrave Connect. Web. 14 Oct. 2015.

Rowling, J. K. Harry Potter og de vises stein. Trans. Torstein Bugge Høverstad.6th ed. Oslo: N. W. Damm \& Søn, 2000.

Schmitt, Norbert, Xiangying Jiang, and William Grabe. "The Percentage of Words Known in a Text and Reading Comprehension.” The Modern Language Journal, 95.1(2011): 2643. Wiley Online. Web. 14 Oct. 2015.

Serafini, Frank. "Expanding Perspectives for Comprehending Visual Images in Multimodal Texts." Journal of Adolescent and Adult Literacy 54.5 (2011): 342-50. PDF file.

Smetana, Linda, et al. "Using Graphic Novels in the High School Classroom: Engaging Deaf Students with a New Genre." Journal of Adolescent \& Adult Literacy 53(3) (2009): 228-40. PDF file.

Stoller, Fredricka L. "Viewing Extensive Reading from Different Vantage Points." Reading in a Foreign Language 27.1 (2015): 152-9. Web. 19 Oct. 2015.

Syma, Karya K., and Robert G. Weiner, eds. Graphic Novels and Comics in the Classroom: Essays on the Educational Power of Sequential Art. Jefferson and London: McFarland and Company, 2013. ProQuest. Web. 1 Oct. 2015.

Varnum, Robert, and Christina T. Gibbons, eds. The Language of Comics: Word and Image. Jackson: U of Mississippi P, 2007. Print.

Whitt, David. ''I can get college credit for reading Batman? That's a joke, right?' Confessions of a Fanboy Professor Teaching Comic Books." Graphic Novels and Comics in the Classroom: Essays on the Educational Power of Sequential Art. Ed. Karya K. Syma and Robert G. Weiner. Jefferson and London: McFarland and Company, 2013. 50-57. ProQuest. Web. 1 Oct. 2015.

\footnotetext{
${ }^{\mathrm{i}}$ http://www.oslocomicsexpo.no/2015/

ii $\underline{\text { htp://www.tegneseriemuseet.no/3-det-nasjonale-tegneseriearkivet }}$

iii http://www.tegneseriearkivet.no/pls/htmldb/f?p=105:1:0

${ }^{\text {iv }}$ http://www.dagbladet.no/tegneserie/

${ }^{v}$ www.klartale.no

${ }^{\mathrm{vi}}$ www.boksøk.no

vii http://dropeverythingandread.com/

viii For resources and examples, see http://www.slj.com/2016/03/programs/pictures-of-the-week-dahlstrommiddle-school-celebrates-sljs-battle-of-the-books/ and http://blogs.slj.com/battleofthebooks/

${ }^{i x} \underline{w w} \cdot$ boksøk.no
} 